\title{
Questioning the Paradoxes of "Other" Modernities: Uncovering Architecture in the Political Agenda of Iran and Turkey 1920-1940
}

\author{
Ezgi Yavuz and Baharak Tabibi
}

\begin{abstract}
During the early 1920s, Iran and Turkey underwent a rapid modernization process under Reza Shah and Atatürk. Opened a new era in modern Iran's social, political and cultural histories, Reza Shah's objectives were compared to his contemporary Atatürk's in their inventory projects of modernization, centralization and nationalism. In this context, architecture as a "concrete" product of the states' modernization process became an instrument to consolidate the leader's political conduct.

Through a comparative analysis of the Persian and Ottoman Empire's transformations into modern states, this study gives an overview on the socio-political and cultural-political histories of the early $20^{\text {th }}$ century Turkish and Iranian modernity. It argues that despite the parallelism in the political strategies of Reza Shah and Atatïrk, modern architecture as an outcome of the political agenda, revealed differently in Iran and Turkey during this period.

It is believed that, the paradoxes of "other" modernities in the case of Iran and Turkey were indeed not so much related with the Western canonic definition of modernity as it was with the states' political ideologies. Questioning the paradoxical characteristics of modern architecture in the new established capitals, this research indicates the interaction between architecture and politics.
\end{abstract}

Index Terms-Architecture, modernization, modernity, politics.

\section{INTRODUCTION}

Throughout the early 1920s, Iran and Turkey underwent a rapid and "forced" modernization process under Reza Shah and Atatürk. Called as the "icons of authoritarian modernization", the leaders' reconstruction policies were effective in transformation of the new, modern nation-states. This paper deals with the parallel approaches of two leaders and how their political strategies managed different outcomes in terms of architecture. This study treats the issue with a comparative analysis regarding the histories of the two states in social, political and cultural senses. But it mainly points out the divergent consequences of the reforms which imply, in a way, the paradoxical characteristics of modern architecture. Accordingly, this study points out that the contradictions and complexities in the experience of modernity in Iran and Turkey were in fact embedded in the political strategies of these new regimes to be modified and applied to their westernization projects.

Manuscript received August 4, 2013; revised October 14, 2013.

Ezgi Yavuz is with the Middle East Technical University, Turkey (e-mail: ezgi_yavuz@yahoo.com).

\section{CONTENT}

In 1934, Reza Shah was invited by Mustafa Kemal Atatürk for an official visit to Turkey (See Fig. 1); with an elaborate welcoming ceremony, the "great guest" was met by a densely crowded population in the capital, which was the beginning of a "new political arena" for the new established states in Iran and Turkey. The leaders' seminal encounter for their common attempt towards Westernization has often been introduced as influential in transforming the states from their traumatic pasts towards effective social, political and cultural progress.

In the context of the Middle East, Iran and Turkey were the two "underdeveloped" countries experiencing a "radical", "rapid" and "forced" modernization process during the first decades of the $20^{\text {th }}$ century [1].

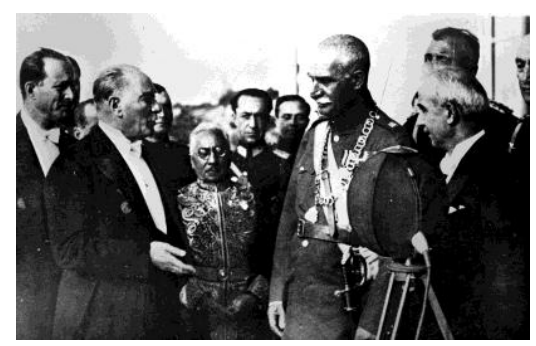

Fig. 1. Reza Shah Pahlavi's state visit to Turkey. (office of the prime minister, directorate general of press and information archive)

Called as the "icons of authoritarian modernization" [2], Reza Shah and Atatürk shared parallel objectives and guidelines in the implementation of their inventory of reconstruction projects of westernization, centralization and nationalism. In the path of reform, the two leaders' revolutionary attitudes displayed similarities in asserting independence from foreign domination, building up the infrastructure of a modern nation-state, encountering the religious impediments, neutralizing the development of arbitrary rulers, executing a Western model of modernity and cultivating national culture and tradition [1].

In the wake of the countries' state contact, Reza Shah imbued his reformist program with new content he witnessed during the twenty-eight day travel to Turkey. In the development of his nation, he involved in cultural transformation such as language and custom reforms as well as developments in educational system as it had been achieved by his contemporary, Mustafa Kemal Atatürk in Turkey. Although the leaders differentiated in their legacy, in the socio-cultural context, both Reza Shah and Atatürk participated in an attempted transformation of their nations. 
Despite the similarities in their political objectives, in fulfilling their approaches, however, the leaders followed different paths; while secularism was emphasized as the central political claim in the ideological content of Atatürk, associated with the political narrative of Iranian modernity, nationalism was defined as the primary doctrine in Reza Shah's political achievements [3], that expanded parallel to a will towards modernity. Thus, it was precisely based on their political precedence that the two leaders differentiated in their revolutionary designs for their societies. The concrete manifestation of the discrepancy in Reza Shah and Atatürk's political strategies can be initially observed in the construction policies for the (re)establishment of the modern capitals of Tehran and Ankara.

In 1923, Atatürk designated the capital of the newly founded Republic as Ankara, as an outcome of his major political ideologies. To start from scratch, while repudiating all ties with its Ottoman and Islamic past, the leader constituted the new but the modern in both institutional and conceptual frameworks. Within a year, in 1924, Reza Shah reconfigured the urban fabric of Tehran to stage his reformist approach. In the case of Iran, modern was identified with the national, through which it was operated. This notion of national modernity was carried out by promoting the legacy of Iranian ancient past while negating all connections with the Islamic tradition.

In his envisagement for building the modern nation and society, Reza shah (See Fig. 2) listed as high-modernist the planners, engineers, architects, scientists, and technicians, whose skills and status he celebrated as the designers of the new order [4]. Bringing about huge, utopian transformations in Turkey, Atatürk adopted a similar approach in reconstructing his nation. While the builders of the modern nation-state strove to shape the new system, their political ideology one way or another oriented the fabric of modern capitals in Iran and Turkey. In their approach to urbanization, both Reza Shah and Atatürk pursued similar routes in delegitimizing the previous Ottoman and Qajar regimes; however, while the essence of Reza Shah's intention in re-designing the society was the "urban-clearance" through demolishing the traditional feature of the old capital, declaring Ankara as the center of the new state, Atatürk operated the notion of "old-versus-new" as a dominant slogan to legitimize his reconstruction policies.

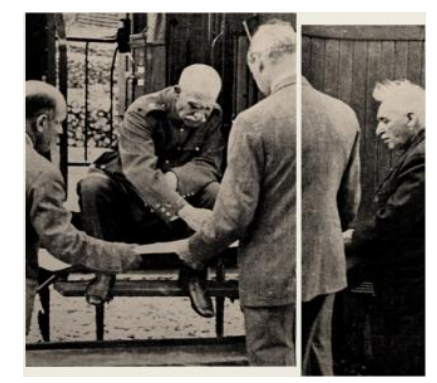

Source: Reza Shah-e Kabir (Reza Shah the Great), Tehran 1940. Archives: Iran National Archives Organization, Tehran

Fig. 2. Reza Shah's drive for modernization destructing Tehran, reading project by the shah

In their revolutionary design, architecture in Iran and
Turkey, consequently, became a convenient instrument in politicians' intentions to crystallize their westernization programs. Shortly after the coup d'état of 1921 and the establishment of the Pahlavi dynasty in Iran, architecture became in the service of the new dynasty and political power. The Shah "engaged in grand-scale urban reconstructions, overseeing them in detail, choosing architects as well as architectural style" [5] to reconfigure the feature of urban capital according to its very political strategies of secular nationalism and modernization. In Turkey, although architecture was not directly under the authority of the state, Republican architects and planners were tied to political power shifts for an appropriate image in shaping the thoroughly westernized, modern and secular nation.

According to Louis Althusser [6], the state used various implements (including family, media, religious organizations, educational system, legal system, politic, syndicate, and culture) to maintain its ideological practice, which was introduced as the "state ideological apparatus". Within the context of this statement, architecture can be considered as an ideological tool in the case of Pahlavi Iran and Atatürk's Turkey effective for the authoritarians to sustain their political ideals towards westernization.

As mentioned before, modernization and nationalism constituted the base of the ideological leanings of Reza Shah and Atatürk in legitimizing their political systems. Considering Thompson's definition of the "modes of operation of ideology" [7], the new regimes, in practice, used 'rationalization' and 'unification' as the forms to implement their westernization projects. Referring to national unity and collective identity, unification [7] overlapped the definition of nationalism, which clarifies the Shah's emphasis on "looking to the past as reference for the future greatness of Iran" [8].

Introducing the new nationalism emerging in the non-western world, Hans Kohn indicated that, "outside the west, nationalism arose [...] at a backward stage of social and political development [where] it found its first expression in the cultural field;" and as it "looked for its justification [...] to the heritage of its own past, the new nationalism [... received its original impulse from the cultural contact with some older nationalism." [9].

In this respect, linking the Pahlavi Monarchy to its Iranian legendary past of Achaemenian and Sassanian golden age, nationalism was a political strategy in consolidating the monarch's modernization polity. In the cultural context, under the influence of the state, nationalism penetrated into the vocabulary of form and style; the revival of the pre-Islamic Persian grandeur in architectural practice symbolized the Iranian cultural unity and identity, which cultivated the Shah's very notion of nationalism.

By the late 1930s (See Fig. 3- Fig. 5), Tehran became the showcase of the Shah's political vision. The feature of the modern capital started to embrace the new symbolic directions embedded in historicism; a large number of governmental and administrative buildings besides a dozen of monumental architecture were erected in Achaemenian and Sassanian revival style since these structures "were perceived as native to the land and its history" [10].

The Pahlavi's nationalistic practice was, consequently, 
"not only an exercise in internal political consolidation, it was also an attempt to project an image outward to the world, declaring the nation's compatibility with and desire to join the new universalism of modernity" in Marashi's terms [11]. In a similar manner, the new Republic motivated the Kemalist nationalistic vision in order to access the contemporary universal civilization [12].

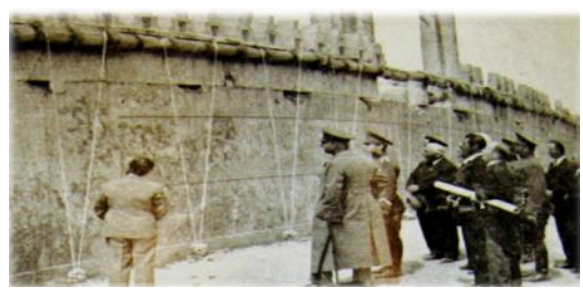

Source: Reza Shah-e Kabir (Reza Shah the Great), Tehran 1940. Archive: The Institute for Iranian Contemporary Historical Studies

Fig. 3. Reza Shah and Mohammad Reza Shah at Persepolis accompanied by Herzfeld, 1937

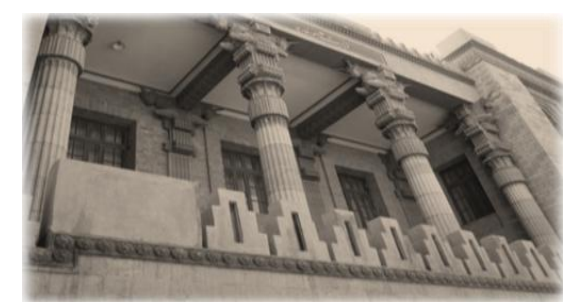

Fig. 4. The ministry of foreign affairs by Gabriel Gueverkian@Baharak Tabibi

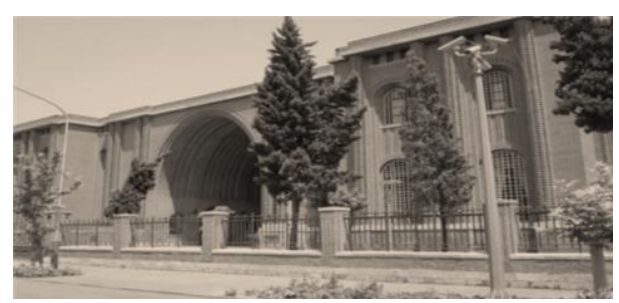

Fig. 5. The archeological museum (muze-ye Iran bastan 1931-1939) by Andre Godard@Baharak Tabibi

However, although in the Kemalist nationalist conception, the glorification of national heritage and history was fundamental in the "development of the idea of national unity and identity," [12] the integration of the nation to the world civilization was another notion in this conception in moving forward towards modernity. In Kemalist idealized nationalistic practice, "nations are many but the civilization are one and for the progress of the nation it is necessary to participate in this one civilization" [13]. As a result, in taking step forward towards contemporary civilization, Turkey needs to borrow the demands of universal modernity from the West. This new spirit of modernity advocated the emergence of modernism in architecture as well. In this context, the leaders' nationalistic strategies in both Iran and Turkey were influential in cultivating their very contemporary projects of modernity.

In constructing a logical justification for the political ideologies, rationalization was another formula in Thompson's "modes of operation of ideology," [7] which overlapped the definition of modernization experienced in contemporary Iran and Turkey. The common characteristic of Reza Shah and Atatürk's revolutionary manner appeared to be the notion of reform from above, which necessitated a series of reformist legislations and principles to justify the leaders' very rationalist and modernist projects in bureaucracy, industry, technology, education, legal and socio-cultural system. Modernism, as the most appropriate expression of the rationalist and positivist ideals of the new regimes, was celebrated as a new lexicon of architecture in Iran and Turkey (See Fig. 6- Fig. 11).

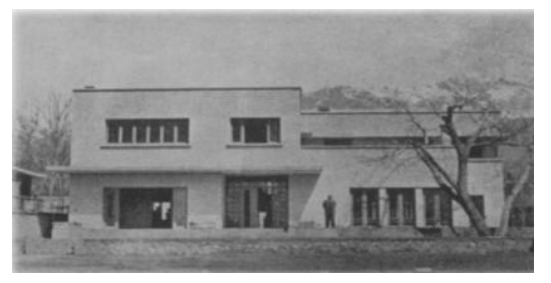

Fig. 6. A villa by mohsen foroughi, tehran, archive: Architecte, 1946.

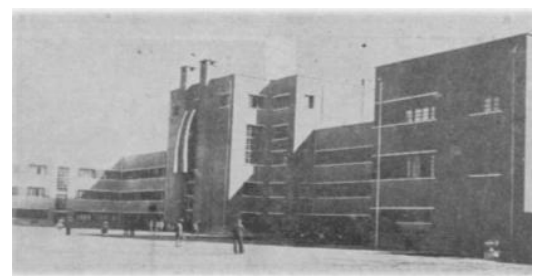

Fig. 7. Girls' school of art (honarestan-e dokhtaran,1935-1938) by vartan hovanesian, archive: Architecte, 1946.

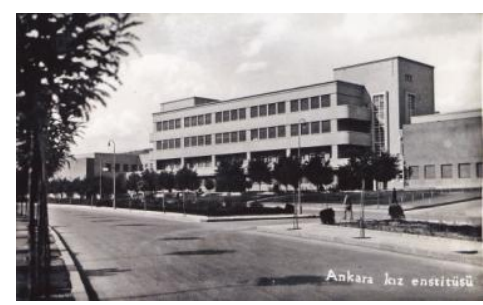

Fig. 8. Egli, 1smet paşa girls institute, ankara, 1930. (atila cangır, 2007, cumhuriyetin başkenti, ankara: ankara üniversitesi kültür ve sanat yayınları, volume 3.)

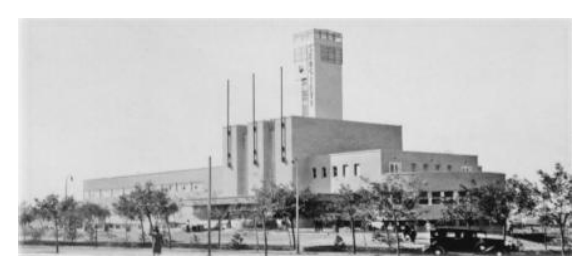

Fig. 9. Balmumcu, the exhibition hall, ankara, 1933-34. (atila cangır, 2007, cumhuriyetin başkenti, ankara: ankara üniversitesi kültür ve sanat yayınları, volume 3.)

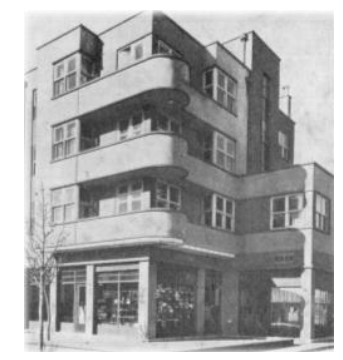

Fig. 10. Hüsnü, rental house for the children's protection fund, ankara, mid 1930s. (sibel bozdoğan, (2001). modernism and nation building. seattle and london: university of washington press.) 


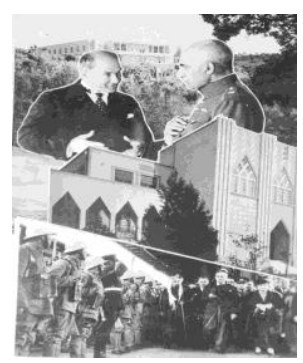

Fig. 11. A collage from office of the prime minister, directorate general of press and information archive.

On the eve of disseminating and consolidating their progressive ideas, architecture was a catalyst and an appropriate instrument with a capacity of orienting the society. As a "universalist, reformist, technological, and reductivist project" [14], modern architecture, correspondingly, was "the expression of a scientifically, aesthetically and politically 'correct' architecture" [15].

The metamorphosis in the architectural discourse of Pahlavi Iran was the work of Reza Shah. Instigated revivalism in the city spectacle to reinforce his nationalistic ideology, the Monarch superimposed an avant-gardist tone into the traditional pattern of the capital to express his modernist projection. While the state's "anti-colonialist" vision [10] generated a nationalistic language in the administrative architecture, the concrete production of the Monarch's modernization concept aroused in private architecture, social and cultural institutions and military structures to answer the demands of secular-elites' life-style. The architecture of these private commissions followed the imported principles of international style.

The existence of modern architecture in Republican Turkey was a measure to prove the image of the modern nation-state.

The new regime embraced modernist ideology as one of its initial ideological outlook; however, the tangible product of this vision in architectural culture was not in the authority of the state as it was in the initiative of the Republican architects. In this manner, both local and foreign architects portrayed themselves as the "republican ideologues" [15] to disseminate those imported avant-garde taste in entire public and private built structures.

According to Bozdoğan [15], "In Kemalist idealized formulation, contemporary civilization was not the exclusive monopoly of Europe, [...] rather, it was the stock of accumulated scientific knowledge, methods and tools, world views and life styles that constituted the very substance of historical evolution of humanity and should be seen as the property of all nations." Modern architecture during the early Republican period, accordingly, was seen as an appropriate consolidation policy of the new but the modern state. Modern Republican architecture, thus, abstained from the implementation of the historical references, which symbolized the backwardness of its own past. The Pahlavi's revolutionary project towards Westernization however had dual structure in its essence. Although the politicization of the Iranian national heritage preoccupied as a particular dynamic in the Monarch's modernist ideology, in a similar manner as it appeared in Turkey, the adaptation of the aspects of the Western civilization was a result of the Shah's desire of elevating his country to be equal to the West.

\section{CONCLUSION}

In the crystallization of the states' political ideologies in Pahlavi Iran and Atatürk's Turkey, architecture was an appliance cultivating the leader's nationalistic and modernist perspectives. However, despite the parallelism in the political strategies of Reza Shah and Atatürk, as a concrete outcome of political agenda, new architecture revealed differently in Iran and Turkey. This discrepancy in the architectural discourse was particularly based on the leaders' approaches towards westernization, which were embedded in the political dynamics of their own contexts. At this point, in answering the question whether the so-called "local experiences" [16] of modernity is the 'other' or not, it can be said that the contradictions and complexities in the non-Western cultures and societies in the case of Pahlavi Iran and Atatürk's Turkey cannot be defined within the notion "otherness". Pahlavi Iran and Atatürk's Turkey experienced a different version of modernity to modify and apply within their own historical circumstances. The paradoxes of "other" modernities in the cases of Iran and Turkey, were, indeed not so much related with the Western canonic definition of modernity as it was with the new regimes' political ideologies.

\section{REFERENCES}

[1] G. Lenczowski, Men of Order: Iran under the Pahlavis, Stanford: Hoover Institution Press, 1978, pp. 365-366.

[2] T. Atabaki and E. J. Zürcher, Men of Order: Authoritarian Modernization under Atatürk and Reza Shah, London and New York: I. B. Tauris, 2004.

[3] A. Marashi, "Performing the nation: The Shah's official state visit to Kemalist Turkey, June to July 1934," in The Making of Modern Iran: State and Society under Riza Shah, 1921-1941, Ed. S. Cronin, London and New York: Routledge, 2003, pp. 8-11.

[4] J. C. Scott, Seeing Like a State: How Certain Schemes to Improve the Human Condition Have Failed, New Haven: Yale University Press, 1998 , pp. 88.

[5] M. Marefat, "Modern and Islamic, changing cities," Harvard Design Magazine, pp. 44, 1997.

[6] L. Althusser, Ídeoloji ve Devletin Ideolojik Aygitlarl, trans., A. Tümertekin, İstanbul: Ithaki Yayınları, 2006, pp. 169.

[7] J. B. Thompson, Ideology and Modern Culture, Stanford: Stanford University Press, 1990, pp. 61, 64.

[8] R. Graham, Problems of Culture, The Illusion of Power, London: Croom Helm, 1978, pp. 192.

[9] H. Kohn, "Western and eastern nationalisms," in Nationalism, ed., J Hutchinson and A. D. Smith, Oxford and New York: Oxford University Press, 1994, pp. 164.

[10] T. Grigor, "The (inter)National of an uneven modernity: Architectural politics in Pahlavi Iran," in Modern Architecture in the Middle East, Docomomo International, 2006, pp. 36, 38.

[11] A. Marashi, "Nations and nationalism in Iranian historiography," in Nationalizing Iran: Culture, Power and the State 1870-1940, Seattle and London: University of Washington Press, 2003, pp. 90-120.

[12] L. Köker, Modernleşme, Kemalizm ve Demokrasi, İstanbul: İletişim Yayınları, 1990, pp. 81.

[13] M. Matossian,“ Ideologies of delayed development," in Nationalism, ed., J. Hutchinson and A. D. Smith, Oxford and New York: Oxford University Press, 1994, pp. 220.

[14] G. Baird, The Space of Appearance, Cambridge and Mass: MIT Press, 1995, pp. 242.

[15] S. Bozdoğan, Modernism and Nation Building, Seattle and London: University of Washington Press, 2001, pp. 152.

[16] A. Mirsepassi, Intellectual Discourse and the Politics of Modernization: Negotiating Modernity in Iran, Cambridge: Cambridge University Press, 2000, pp. 1. 


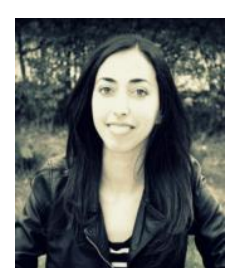

Ezgi Yavuz is a Ph. D candidate in Architectural History Program at Middle East Technical University, Ankara. She was born in Kadirli-Turkey on 12 June 1982. She received B. Arch from the Department of Architecture at Uludağ University, Bursa, Turkey, 2004; and M. Arch from the Department of Architecture at Gazi University, Ankara, Turkey, 2007. The major field of her study is the $20^{\text {th }}$ century art and architecture, modern Turkish architecture, the relationship between art and architecture.

She had worked as an architect at A\&Z Aksu Architecture Office in 2006. She presently works at Middle East Technical University in the Department of Architecture as a research assistant. One of her publications is "Sanatla Kurulan İlişki: Zaha Hadid ve Mimarlıkta Soyutlama ( The Relationship with Art: Zaha Hadid and Abstraction in Architecture),", in Kültürel Bellek ve Estetik Yansımalar, Ankara: Ankara Üniversitesi Yayını, 2011. She currently researches the collaboration of plastic arts in the postwar Turkey.

Ms. Yavuz is a member of Chamber of Architects of Turkey.

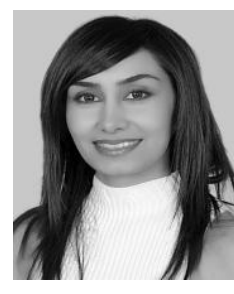

Baharak Tabibi is a $\mathrm{Ph}$. D candidate in Architectural History Program at Middle East Technical University, Ankara. She was born in Tehran on 08 January, 1978, Baharak Tabibi received B. Arch from the Department of Architecture at Uludağ University in 2000 and M. Arch from METU in 2005. The major field of her study is the $20^{\text {th }}$ century art and architecture, modern Iranian architecture, architecture in the Republican Turkey, politics and space, women and gender studies, architectural exhibition and representation.

She has worked as design office coordinator in various architectural firms and participated in diverse large-scale governmental, educational, commercial and residential building projects since 2000. She had worked as a part-time assistant at METU from 2008 to 2010. Her articles, "Gendered Empowerment in the Pahlavi Court: Shahbanu Farah's Patronage of Arts and Architecture", and "Acculturating A Nation: Artistic Festivals and Cultural Revolution under the Pahlavis" are accepted to be published. She currently works on modern Iranian art and architecture during the second Pahlavi era. Mrs. Tabibi is a member of Chamber of Architects of Turkey. 